\title{
OPINIONS OF IBN KHALDUN ABOUT THE INDIVIDUAL NEEDS FOR EDUCATION-TEACHER AND TEACHING PROFESSION*
}

\author{
Hacer ÂŞIK EV1
}

\begin{abstract}
In this research, the researcher tries to elicit opinions of Ibn Khaldun about the individual needs for education-teacher and the teaching profession. Relevant documents have been reached primarily through literature review, and then they were analyzed through document analysis and content analysis. According to Ibn Khaldun, education and teacher are necessities for human being by virtue of various reasons. Teacher's qualification in his/her field and ability to teach are factors that determine student success. Therefore, taking each science and art from their best teachers is counted as effectual fulcrum in everywhere and in all communities. Also, taking courses from a great number of teachers is another factor that determines student success. Education activities and teaching profession were not institutionalized at first and they were not accepted as an art that requires specialty. When numbers of Muslim countries started to spread and extend; when events started to increase and overlap, necessity of bringing out provision from verses of the Quran increased and while those provisions were being brought out, laws and rules which would protect from mistake started to be needed, then education activities started to become specialty.
\end{abstract}

Keywords: Ibn Khaldun, education, teacher, teaching profession.

\section{İBN HALDUN'UN BİREYIN EĞİTIM-ÖĞRETMEN İHTIYACI VE ÖĞRETMENLİK MESLEĞİ İLE İLGILİ GÖRÜŞLERİ}

\section{ÖZ}

İbn Haldun'un bireyin eğitim-öğretmen ihtiyacı ve öğretmenlik mesleği ile ilgili görüşlerinin ortaya çıkartılmaya çalışıldığı bu araştırmada öncelikle literatür taraması yapılarak konu ile ilgili dokümanlara ulaşılmış, daha sonra bunlar doküman incelemesi ve içerik analizi ile analiz edilmiştir. İbn Haldun'a göre insan için eğitim-öğretim ve öğretmen çeşitli sebeplerden dolayı zorunlu bir ihtiyaçtır. Öğretmenin alanındaki yeterliliği ve öğretme konusundaki becerisi ögrrencinin başarısını belirleyen unsurlardandır. Bu nedenle, her ilim

\footnotetext{
* This research based on the author's doctorate work published as "Ibn Khaldun and Education".

${ }^{1}$ Yrd. Doç. Dr., Celal Bayar Üniversitesi, İlahiyat Fakültesi, İlköğretim Din Kültürü ve Ahlak Bilgisi Eğitimi A.B.D, hacerev@gmail.com.
} 
ve sanatı onu en güzel öğreticilerden almak her yerde ve her toplulukta geçerli dayanak sayılmıştır. Ayrıca çok sayıda öğretmenden ders almak da öğrencinin başarısını belirleyen bir başka unsurdur. Ë̆itim-öğretim işleri ve öğretmenlik bașlangıçta kurumsallașmamıș ve uzmanlık gerektiren bir sanat olarak da kabul edilmemiştir. Müslüman ülkelerin sayıları çoğalıp genişlemeye, olaylar artarak üst üste gelmeye başlayınca ayetlerden hükümler çıkarma zorunluluğu artmış ve bu hükümler çıkarılırken hatadan koruyacak kanun ve kurallara ihtiyaç duyulmaya başlayınca da eğitim-öğretim işleri uzmanlık haline gelmeye başlamıștır.

Anahtar Kelimeler: İbn Haldun, eğitim-öğretim, öğretmen, öğretmenlik mesleği.

\section{INTRODUCTION}

Ibn Khaldun (1332-1406) who was born in 1332 in Tunisia, lived at the second half of XIV century that coincided the last period of theMiddle Ages in which The Renaissance started to sprout in Europe and beginning of XV century (Sâtî el-Husrî, 2001: 59). Even though he was keen on learning science from his Adolescence period, he could not continue his education because he had lost his parents and teachers from epidemic Black Death that ravaged Europe, Asia and North Africa in 1348 (Adıvar, 1950: 739) and he passed a long period of his life in political works and developments actively in a turbulent political time that took part in power, which continuously passed into other hand. However, at the beginning of his forties which can be called second half of his life, he retired from active policy with a radical decision and he abstracted himself in Salama Castle in a remote place and started to put his experiences on paper. Even though he had to involve in policy, he spent the following period of his life by being Muslim Judge teacher in madrasah and working on his works (Ibn Khaldun, trans. Akyüz, 2004).

Ibn Khaldun said that he had established "IIm-i Tabiat-i Umrâni", which is a science that deals with the conditions and lives of peoples who had lived in past ages; examines the changes occurred in their lives, their reasons of taking the country and government, nature of human communities, settled lives and migrant lives, migrations, population movements, establishing country, refreshments and collapses of established countries, production and consumption, science and art, profit and loss changes of those situations and reasons of changes (Ibn Khaldun, trans. Ugan, 1989).

Ibn Khaldun is considered and recognized not only as pioneer of sociology that he called as "İlm-i Tabiat-i Umrâni", but also history philosopher. He criticized historians' techniques of transferring situations as "...when transferring an information they do not research center and justice, they drop the reins without examining and getting into research" (Ibn Khaldun, trans. Ugan, 1989) and he developed a 
new technique by putting some rules and principles and he got established in philosophy of history by putting forward that instead of just telling the historical events, it was needed to be thought in cause-effect relationship with a critical approach, in social law settings (Hançerlioğlu, 1999: 48).

At the end of Middle Ages in which endorsement writing habit with just explanation purpose became widespread; all branches of information was worked on; but production of original idea became slower, Ibn Khaldun was different from encyclopedic scholar type in some aspects by putting forth opinions that beyond the age he lived (Hançerlioğlu, 1999).

The thought that Ibn Khaldun, who had an intelligence that had so much original ideas, could also have valuable views in the field of education formed the starting point of doctorate research that author tried to put forth educational view of Ibn Khaldun. The author considered that Ibn Khaldun had important views about education in Muqaddimah that he had written for introduction to el-İber, which was considered as world history and his most important work,in preparatory research about the topic. However, when researches about Ibn Khaldun are examined, it is understood that the researches are generally about sociology, history, philosophy and policy; his opinions about education have not been examined enough (Âşsk Ev, 2012: 3-4). Resulting from all these reasons, Ibn Khaldun's opinions about education have been investigated as doctorate research. In also this research, opinions of Ibn Khaldun about individual need for education and teacher are tried to bring out based on the author's doctorate work published as "Ibn Khaldun and Education".

\section{PEOPLE NEED EDUCATION}

According to Ibn Khaldun, humanity consists of body and soul (lowerself) (Ibn Khaldun, no date: 517) body and organs are like instruments of the spirit (Ibn Khaldun, no date: 97). In Islamic literature the terms soul, lowerself and heart, which are used to describe structure of human psychology, represent non-physiological way of human being when used to generally though they represent different functions time to time (Hançerlioğlu, 1978: 238). Just as energy is perceived as light, heat and action, which have eternal reflections, not as an object that is perceived automatically, also humanity is perceived with the mind representing light that has external reflection, with the soul representing the heat and with the lowerself that represents the action. Although two different terms, mind and soul, are used, in fact they are same in substance, namely; because of ruling the body it is called "soul", because of apperceiving mental objects it is called "mind" (Keklik, 1996: 187-188). 
In respect to Ibn Khaldun, human being consisting of body and soul (Ibn Khaldun, no date: 517) differs from other living creatures with mind (ability to think) and predominates (Ibn Khaldun, no date: 42). God gave human being mind and hand while giving each animal an organ to defend their own lives. Hand is an organ that was prepared and created for arts with service and support of thought (Ibn Khaldun, no date: 42), as for the mind is a power that is used for self-actualization and it is a power that makes superior and differs from other animals and living creatures (Ibn Khaldun, Trans. Uludağ, 2004: 766). He defines the mind as an ability that separates human being from animals and makes superior (Ibn Khaldun, no date: 42), a power given to human beings to make a living and a tool that reaches science and arts (Ibn Khaldun, no date: 490). Hand and head are two main organs for unity body and soul (Ülken, 2001: 308).

According to Ibn Khaldun, here are the functions of mind:

Mind is natural tool for understanding truth, and giving right decision is possible with it (Ibn Khaldun, no date: 535-536). Mind also fulfils main dynamic and organizer job of mental life. Mind is sometimes source and origin of human behaviors happening in order, and sometimes it is source and origin of appearing a science that does not exist in mind before to head for intended. Namely, idea heading to intend, when wanted to accept or refuse by thinking its positive and negative ways, if object is only one, middle term that forms two sides will show up to itself. If several kinds, it will head for getting other medium in this time. (With this medium) it will take the road for intended. It is the nature and idea of separating human being from animal (Ibn Khaldun, no date: 534-535).

While Ibn Khaldun emphasizes on having mind or belief as basic distinctive feature of human being, at the same time he considers as an important aim to improve this ability. Because "Human beings are ignorant from their nature, because there is hesitation in their science, on the other hand they are scholars from knowledge and art that they earn, forasmuch they got everything they want to learn by basing on logical rules and industrial conditions (Ibn Khaldun, trans. Uludağ, 2004: 772-775). Human nature and essence showed us that because of essence they are unwise and because of earning knowledge they are wise. "God created man from blood clot. Read in the name of your Lord who taught by the pen and taught man that he knew not." These verses of the Quran tell humanity and its two types that one is native, the other one is kesbî (situation that being ignorant from their nature, having knowledge from gained information) (Ibn Khaldun, trans. Uludağ, 2004: 775). Human beings comprehend the truth by mind; they learn what they want to know,

22 | Celal Bayar Üniversitesi Sosyal Bilimler Dergisi - Cilt: 13, Sayı: 4, Aralık 2015 
make right decision and find a chance for self-actualization, so they need to improve this ability.

In view of Ibn Khaldun, development of mind/consciousness determines the quality of human behaviors. Constructive (cause) power which is a function of mind/consciousness will work successfully if it is under the control of another function, knowing power (wise). Because of the fact that human being activities are limited to their knowledge; their knowledge is limited to their activities, so beginning of business is the end of thought, end of the thought is beginning of business (Ibn Khaldun, trans. Uludağ, 2004: 767-768) there is a relationship between behavior, thought and knowledge, so it is important to develop ability to think. Quality of behaviors is closely related to how developed ability to think in a way (Âşık Ev, 2012).

However, human's power of mind/consciousness or thought cannot be developed automatically; there is a need for education to develop that power. According to Ibn Khaldun, as food and nutrition develop the body, so education develops and matures human soul and mind. Human soul, which is like a baby when came in world firstly, is developed and matured with earning natural faculties in science and arts (Ibn Khaldun, editor, Uludağ, 1977: 104-105). While education generally provides mental development, it also makes human mind sharper and makes thought brighter (Ibn Khaldun, no date: 433), develops perception and makes mind learn easier by perceiving faster.

In respect to Ibn Khaldun, people, who have tendency both goodness and badness, separate good from bad, ugly and disordered thanks to education and so they become different from stray animals (Ibn Khaldun, trans. Uludağ, 2004: 769).If people are informed and trained about what ugly and disordered things are, how to distinguish them from good things and if people repeat good ones, they can produce good and nice things by becoming different from animals at the end of this training (Âşık Ev, 2012). Otherwise, human being lowerself mostly does not demand virtues, does not show interest in people who have virtue and do not compete each other to give their rights (Ibn Khaldun, no date: 228). Civilization level of societies is in direct proportion to education facilities they have. Differences seen in point of intelligence and living between East and West African people and between sedentary and Bedouin people were results of education. Having good education and arts they have provides sedentary people to be more intelligent and smarter (Satî el-Husrî, 2001:189).

Ibn Khaldun emphasizes on importance of education at early ages. For him, education, which is given at early ages, is more effective and builds a tough basis for the next (Ibn Khaldun, trans. 
Ugan, 1989: 154). In other words, this basis education will be determiner of next education in point of quality and quantity (Âşık Ev, 2012: 27).Ibn Khaldun emphasizes on importance of education at early ages by informing "when children are in puberty and get rid of oppression of their parents, they grow lazy because of youthfulnessthey daydream, whereas they have to obey their parents' orders and submit decisions as long as they are under the tutelage (Ibn Khaldun, no date: 539-540).

Ibn Khaldun, who deals with whether heredity or environment is effective on education, (Ibn Khaldun, no date: 384) says that "If colors of banes are settled in a person completely; if their colorings become darker and if his good habits are gone, neither his ancestors nor his genealogy being nice and noble will not benefit" (Ibn Khaldun, no date: 373 ).

\section{PEOPLE ALSO NEED RELIGION'S EDUCATION}

Ibn Khaldun indicates that people need religion's education especially in development of social and ethical motives. For him, human being genesis is inclined to both goodness and badness. Religion creates a top control mechanism that retards negative effects of selfish tendencies by impelling altruistic motives. "If a person who has tendency to both goodness and badness is left alone and do not improve by being liable to religion, he/she will be closer to bad habits" (Ibn Khaldun, no date 127).

Ibn Khaldun tries to explain the importance of religion's education and power of civilization by giving examples of Arabians: Arabians were barbaric people, they did not care about implementation of rules, protecting people from loss and damage, preventing people from attacks to each other, Countries taken by force were tend to be ruined fast. Nevertheless, after a revolution occurred in their nature, their nature was painted with a religious color and changed; religious color erased everything they were told and it created an internal and conscientious sanction (Ibn Khaldun, no date: 149-152) .As a result of religion's education, Arabians' barbaric, raider, lawless personalities were improved, their hearts were cleaned (Ibn Khaldun, trans. Ugan, 1989, Vol. I, 379-387).

\section{EDUCATION COMES AFTER PHYSICAL NEEDS}

According to Ibn Khaldun, education, which is a vehicle for having people to possess science and virtue, for setting appropriate to creation purpose being superior to other creaturesby providing development of idea specially given to human being, comes after physical needs. People need food and maintenance in every period of their lives due to their nature, whether rich or poor, all people have to provide food for themselves (Ibn Khaldun, no date: 398).Basic physical needs come before expansion needs and ripeness level.

24 | Celal Bayar Üniversitesi Sosyal Bilimler Dergisi - Cilt: 13, Sayı: 4, Aralık 2015 
Because exigency is real, an object in quality of ripeness is an arm of exigency and derived from it (Ibn Khaldun, trans. Ugan, 1989: Vol.I,307). The reason of coming physicals needs firstly is that living is a must and permanent. However, learning is a luxury or need and this comes after physical needs (Ibn Khaldun, no date: 41). For his opinion, so long as physical needs are provided and economic level is increased, upper needs arise because obligatory needs comes the top of things people want. Without that people achieve obligatory needs, people cannot reach perfection and peace (Âşık Ev, 2012:41).

As a matter of fact, until settled life develops in cities and people become civilized, people think about just things which are obligations for living, because science and industry are needs after obligation things for living are provided. These are results of civilization and develop in proportion as civilization's development and expansion (Ibn Khaldun, trans. Ugan, 1989: Vol. II, 369). Person only after provides necessities, he/she looks for perfection and expansion in life, so purpose of immigration is to become civilized and there is immigration in roots of civilization (Ibn Khaldun, trans. Ugan, 1989: 308), mental science in Andalusia disappeared because they fell in trouble of living (Ibn Khaldun, trans. Ugan, 1989: Vol. II, 448).

\section{THERE IS A MUTUAL RELATIONSHIP BETWEEN EDUCATION AND ECONOMY-CIVILIZATION}

Ibn Khaldun emphasizes especially in education and economy-civilization relationships. According to him there is an interactive relationship between education, development of sciences and economic recovery. It may be not true that priority is given to one and one is seen as another's existence. Because widespread and improvement of education provide improvement of economic recovery and economic recovery provides improvement of sciences. Civilization can be interpreted as a product of these two processes and also can be seen as reason of presence time to time (Âşık Ev 2102).

Ibn Khaldun explains these relationships that affect each other by giving examples: Economic prosperity develops industry and science, mind and opinion develop correspondingly, developed mind understands science and ingenuity quickly and abilities develop. Egyptians', who were at such high level to be caught up, training animals can be given as an example of this (Ibn Khaldun, trans. Ugan, 1989: Vol. II, 450). Because of economical wealth that derived from science and industry's improvement on east, education continued successfully. Western people came to east for education. Civilization and culture enlightened and improved eastern people's minds, and this made them superior than western people in science, mind and 
understanding art (Ibn Khaldun, trans. Ugan, 1989: Vol. II, 448-449). Bagdad, Cordoba, Kairouan, Basrah and Kufa were important science centers at Islam's first years because their population was increased and their civilization level improved, but then their population decreased when their economies turned upside down decreasing prosperities, science and engineering were moved to other cities (Ibn Khaldun, trans. Ugan, 1989: Vol. II, 453). As shown, Ibn Khaldun acclaims that economic recovery develops science and industry recovery, this develops people in society in means of mental and spiritual, against, decreasing and declining in economy cause people to decline in technology and science, and this causes decreasing people's intellectual levels.

However, Ibn Khaldun pointed out this weird situation he observed. For him, expansion ofinformation does not provide an economic welfare mostly. A person, who is absolute in ingenuity, is bankrupt in grant and pleasant of living a wealthy life on earth. Absolute (and ingenuity, quasi to earthly and fortune) that people have is absorbed and share from joy (on earth) is this (Ibn Khaldun, no date: 392).

\section{TEACHER IS AN OBLIGATION AS EDUCATION FOR PEOPLE}

According to Ibn Khaldun, teacher is an obligation as education for people. He lines up the reasons that people need teacher like these: as follows?

1. The first reason is people's incentive of curiosity. In his expression, people want to learn several sciences that can be taught with a special skill, not just possible by understanding and memorizing. Because of the fact that thought wants to learn things which are incomprehensible, people in science or on account of understanding science apply to people, who transfer information that previous prophets warned, and people who are superior; they learn from these. Arabians did not understand books for being Bedouin and illiterate. They asked things that they wanted to learn like reasons of their creation, starting of genesis and mystery of existenceto People of the Book and benefited from them in that situations (Ibn Khaldun, no date: 439).

2. Second reason for people's need for education is that all skills are about body and so they need education of teacher. Whether exist in body or idea, etc., in brain from types of other things like calculation, all skills are secular. All secular things are emotional things, so they need education of teacher. (Ibn Khaldun, no date: 430).

Ibn Khaldun divides "ability" and "skill" from each other with saying having capability and aptitude about a thing is different, being able to that thing personally is different (Ibn Khaldun, no date: 105).

26 | Celal Bayar Üniversitesi Sosyal Bilimler Dergisi - Cilt: 13, Sayı: 4, Aralık 2015 
According to this separation, when ability is power of achievement and predisposition, skill is an adjective that occurred from lots of repetition of obvious verbs (Ibn Khaldun, trans. Uludağ, 2004: 824, 1014). In his words, ability is like udder, it gives milk as milking, it thins and dries when it was abandoned and neglected (Ibn Khaldun, no date: 574-575). Ability becomes skill as using it; unused, undeveloped abilities weakened and rusted. When abilities become skills, a teacher's education is needed. In Ibn Khaldun's words "In skill teaching a master is absolutely needed (Ibn Khaldun, no date: 399).

Ibn Khaldun indicates that abilities people have are in different kinds and levels. For him, when human being self existence is stable and current, Almighty God gives wishinggraves to that self. Without taking any education, in most people's genesis there are abilities like music, reciting poem on rhythm, dancing in harmony, etc. (emotional) (Ibn Khaldun, no date: 11, 425).Idea (thinking) or statement is another ability given to human kind. For development of all these abilities, there is need for education and teacher. "Earning skill for a student in an area actualizes at the rate of teacher's skill as much as education's good (Ibn Khaldun, no date: 400). Because of the fact that teacher's proficiency in field and ability in teaching determines student's success, taking each science and art from their best teachers is counted as effectual fulcrum in everywhere and in all communities(Ibn Khaldun, trans. Uludağ, 2004: 301).

3. Third reason is that human being is the social being. According to Ibn Khaldun, a teacher's help and guidance are necessaries for a social being, human being, to both to continue life and to learn information and skill. Due to being social beings, without helping each other their kind's presence and future are out of the question (Âşık Ev, 2012). For his opinion, there is need for a director that directs forcibly people to help each other for continuation of human kind (Ibn Khaldun, no date: 390).

4. Another reason is a need for a person to whom people can ask and learn what they do not know.

Beside teacher's field and proficiency in teaching, for Ibn Khaldun, taking courses from a great number of teachers is one of the factors that determine student success in education. In proportion as their teachers' number, a habit and skill occurs on students and when becoming stronger, information becomes perfect (Ibn Khaldun, trans. Ugan, 1989: Vol. III, 163).

\section{TIME IS ALSO A TEACHER WHO EDIFIES PEOPLE}

Ibn Khaldun thinks that "time", in other words progress and livings also have educational value. For him, time is also a teacher that has a role for personal development. A person, who cannot learn and understand proprieties of social behaviors and relationships with 
$\overline{\text { advice and counsel from parents and experienced olds who are agree }}$ with parents, leading adults and teacher, will naturally face learning situations he need from in time that goes fast. For that, his teacher will be time (Ibn Khaldun, trans. Uludağ, 2004: 770).

As seen, according to Ibn Khaldun, as well as education and society that have an effective role on appearing and development of abilities, passing time and living progress have also an educational function. Thanks to experiences and livings occurred in time, more effective and more permanent learning comes true. The proverb in our Turkish culture "one misfortune is better than thousands of advice" is stated in Ibn Khaldun's education understanding as "time edifies people, whose parents cannot edify."(Ibn Khaldun, trans. Uludağ, 2004: 770).

\section{INSTITUTIONALIZATION OF TEACHING PROFESSION AND ITS STATUE}

According to Ibn Khaldun's reports, education and teaching profession that showed diversity in beginning of Islam, in Umayyad Dynasty and Abbasid was not institutionalized at first and was not accepted as an art that requires expertise.

When numbers of Muslim countries started to spread and extend; when events started to increase and overlap, necessity of bringing out provision from verses of Quran increased and while those provisions were being brought out, laws and rules which would protect from mistake started to be needed, then education activities started to become specialty (Âşık Ev, 2012: 28).

Ibn Khaldun gives briefly information about necessity and duties of teacher, beside teaching students, teachers' income in time, value given to teacher and processing. Education at Islamic culture, the value that given teacher and learner could not always protect teachers' statue in society, teaching profession's quality, earnings and reputation in history show rises and falls. According to Ibn Khaldun, incomes of people who are busy with religion, including teaching profession, are not generally much, because if a job or service is requisite for development its value will be much, if not, need for it and given value will be decreased.Jobs at issue are not regarded as requisite jobs for majority of people, however, upper classes, who are keen on religion, need these (Ibn Khaldun, no date: 11, 393). Beside social operation, which Ibn Khaldun accepted about income in basic, is available mostly, showing religion's education and service as a less-needed job cannot be a true generalization for always (Âşık Ev, 2012).

Likewise, when these employed people keep off authorities, thanks to their strong personalities their incomes are low. He explains this situation in this way: Religious guidence cannot come

28 | Celal Bayar Üniversitesi Sosyal Bilimler Dergisi - Cilt: 13, Sayı: 4, Aralık 2015 
together with gaining property, it is impossible (Ibn Khaldun, no date: 11, 329) because of being honorable with science stocks they have, religious scholars are keen on their honors as much as being proud towards folk. So, because they do not submit to authorities, they do not have chance to taking share that increases their sustenance in that way from them (Ibn Khaldun, no date: 11, 393).

Teaching profession was not a popular job and its income was low at the time Ibn Khaldun lived. Qualified people were not eager to job but unqualified people were eager, so that situation affected job's prestige negatively. Ibn Khaldun reports that at that time education and teaching profession were not kind of art, which was a living way for short tempered people, and teaching profession was seen as slow and lazy like a tree ruptured from its roots (Ibn Khaldun, no date: 11, 29).Teaching profession that he said it was seen as "an unvalued job" is teaching profession at elementary education, because that kind of understanding is found in tradition. When generally school teachers' income and prestige lowness made smart and qualified people get away from that job,unqualified and inefficient people were held responsible for that job, in fact, it caused arising a literature on school teachers' amusements and foolishness (Parladır, 1984: 68).

When reporting that school teaching was seen as a despised job, Ibn Khaldun thinks that it turns scholars into protector and observer of Muslims of God, stars and universes that will be traced.Because scholars bring people closer to Islam with information, explanation and making comprehensible; they give works by arranging principles and details orderly, regularly and strongly (Ibn Khaldun, trans. Akyüz, 2004).

It is seen that Ibn Khaldun uses three different concepts "teacher", "scholar (wise)" and "professor" about job of enlightening and developing society. It is understood that "teacher" carries out elementary education; "scholar" and "professor" are used as synonyms and they carried out education business at mosque or madrasah, which makes both scientific research and also fulfills secondary education or higher education or both of them. Ibn Khaldun reports that the professor, who is responsible for teaching and spreading science, stays at mosque to give lectures; if the mosque he stays is one of the big mosques that belongs to sultan, permission must be taken from him; if the mosque is general small mosque, lecturing is not depend on permission(Ibn Khaldun, no date: 220).

\section{PARENTS' EXPECTATIONS FROM TEACHER}

It is possible to understand what responsibilities the teacher has at that time from expectations from teacher who was employed for education of Harun Reşid's son that Ibn Khaldun mentions in Muqaddimah. 
Harun Reşid sequences duties that he expected from Halef-i Ahmer when he employed him to his son as teacher: teaching the Quran, sunnah, history and poetry; teaching speaking nicely and at right conditions, ethics and respect to elders; giving information about politics and government administration; teaching importance of time and using time nicely (Ibn Khaldun, no date: 541). Harun Reşid's expectations from teacher can be sequenced as basic religious information, history, grammar that supplies nice and right speaking, ethic that helps socializing and any fields that student is wanted to learn. Here, it is seen that basic expected duty of teacher is to transfer religious and cultural tradition as much as field information (Âşsk Ev, 2012).

At the period that Ibn Khaldun lived, teacher's prior duty is to teach the Quran and basic religious information to children. "Teaching the Quran to children is a sign of religion's signs, so Muslims applied that at all cities. Because becoming Islamic faith and faith principals generally accepted at hearts, which are based on verses of the Quran and some hadith texts, depends on this implementation before everything. For him, the Quran became base (basis) of education, and skills which would occur later, was built on this base. The reason of this is: Children's education is more radical and provides a basis to further education, condition of the thing that built on base happens according to that base and various manners of that base" (Ibn Khaldun, no date: 537-538).

"Sign" Ibn Khaldun said is the thing that community makes it tradition and accepts without arguing its truth. As it is seen, in apprehension, which isextensively accepted at Muslim communities that Islamic culture, based on the Quran, dominates, the head of expectations for teacher is to teach reciting the Quran, Muslim's basic distinctive feature, to children, (Âşlk Ev, 2012).

\section{CONCLUSION}

In this research, which tries to elicit opinions of Ibn Khaldun about the individual needs for education-teacher and the teaching profession, findings can be arranged in brief as:

According to Ibn Khaldun, human being consisting of body and soul differs from other living creatures with mind/consciousness and predominates and development of mind/consciousness determines the quality of human behaviors. However, human's power of mind/consciousness or thought cannot be developed automatically; there is a need for education and teacher to develop that power.

While education provides mental development, it also makes human mind sharper and makes thought brighter, develops perception and makes mind learn easier by perceiving faster. People

30 | Celal Bayar Üniversitesi Sosyal Bilimler Dergisi - Cilt: 13, Sayı: 4, Aralık 2015 
need religion's education especially in development of social and ethical motives, because if a person is left alone and will not improve by being liable to religion, he/she will be closer to bad habits because being tendency to both goodness and badness. However, if education is started to be given at early ages, it will be more effective and it will build a tough basis for the next. Civilization level of societies is in direct proportion to education facilities they have.

In self-development and self-actualization education and environment are more effective than heredity. If colors of banes are settled in a person completely; if their colorings become darker and if his good habits are gone, neither his ancestors nor his genealogy being nice and noble will not benefit.

Education comes after physical needs. Basic physical needs come before expansion needs and ripeness level because exigency is real and living is a must, however, learning is a luxury or need, and this comes after physical needs.

There is an interactive relationship between education, development of sciences and economic recovery. Widespread and improvement of education provide improvement of economic recovery and economic recovery provides improvement of sciences. Civilization can be interpreted as a product of these two processes and also can be seen as reason of presence time to time.

Teacher is an obligation as education for people. There are different reasons for that teacher is an obligation of people: First of all, people want to learn several things that they cannot understand with thought; when they want to learn these, they apply to people, who are superior in science or on account of understanding science apply and they learn from these. Second reason is that, all skills are about body; when abilities become skills, a teacher's education is needed; "in skill teaching a master is absolutely needed." Third reason is that human being is the social being: a teacher's help and guidance are necessaries for a social being, human being, to both to continue life and to learn information and skill. Another reason is a need for a person to whom people can ask and learn what they do not know.

Teacher's proficiency in field and ability in teaching are factors that determine student's success. Taking each science and art from their best teachers is counted as effectual fulcrum in everywhere and in all communities. Also, taking courses from a great number of teachers is another factor that determines student success.

Another teacher that affects self-development is "time". "Time", in other words progress and livings, also have educational value. 
Education and teaching profession were not institutionalized at first and was not accepted as an art that requires expertise. When numbers of Muslim countries started to spread and extend; when events started to increase and overlap, necessity of bringing out provision from verses of Quran increased and while those provisions were being brought out, laws and rules which would protect from mistake started to be needed, then education activities started to become specialty.

Ibn Khaldun reports that incomes of people, who are busy with religion, including teaching profession, are not generally much. For him, reason of this is that jobs at issue are not regarded as requisite jobs for majority of people. If a job or service is requisite for development its value will be much, if not, need for it and given value will be decreased. Only upper classes, which are keen on religion, need these jobs. Also, when these employed people keep off authorities, thanks to their strong personalities their incomes will be low.Teaching profession was not accepted as a popular job and its income was low at the time Ibn Khaldun lived.Education and teaching profession were not kind of art, which was a living way for short tempered people, and teaching profession was seen as slow and lazy like a tree ruptured from its roots.

When reporting that school teaching was seen as a despised job, Ibn Khaldun thinks that it turns scholars into protector and observer of Muslims of God, stars and universes that will be traced. Because scholars bring people closer to Islam with information, explanation and making comprehensible; they give works by arranging principles and details orderly, regularly and strongly.

At the period that Ibn Khaldun lived, teacher's prior duty is to teach Quran and basic religious information to children. The head of expectations for teacher is to transfer cultural and religious traditions beside field information.

As it is seen, opinions of Ibn Khaldun, who is an important historical base of education, about education and teacher despite of the fact that he mentioned at the end of $14^{\text {th }}$ century and at the beginning of $15^{\text {th }}$ century, protects importance and value still in present days where modern education apprehension is effective.

\section{REFERENCES}

ADIVAR, Abdülhak Adnan (1950), "İbn Haldun", İslam Ansiklopedisi, Milli Eğitim Basımevi, Vol. 5, İstanbul.

ÂŞIK EV, Hacer (2012), İbn Haldun ve Eğitim, Tibyan Yayıncılık, İzmir.

HANÇERLIOĞLU, Orhan (1999), "İbn Haldun", Bilim ve Ütopya, March.

32 | Celal Bayar Üniversitesi Sosyal Bilimler Dergisi - Cilt: 13, Sayı: 4, Aralık 2015 
HANÇERLIOĞLU, Orhan (1978), Felsefe Ansiklopedisi, Remzi Kitabevi, Vol. 4, İstanbul.

IBN KHALDUN, (no date), Mukaddime, el-Mektebetü'tTıyariyyetü'l-KübraPublishing, Mustafa Muhammet Printing Press, Egypt.

IBN HALDUN (1977), Şifâu's-Sâil li-Tehzibi'l-Mesail, (Edit. Süleyman Uludağ), Dergah Yayınları, İstanbul.

IBN HALDUN, (1989), Mukaddime (Trans. Zakir Kadirî Ugan), MEB Yayınları, Vol. I, II, III, İstanbul.

IBN HALDUN, (2004), Mukaddime (Trans. Süleyman Uludağ), Third Edition, Dergâh Yayınları, Vol. I, II, İstanbul.

IBN HALDUN (2004), Bilim ile Siyaset Arasında Hatıralar (Turkish, Vecdi Akyüz), Dergâh Yayınları, İstanbul, pp. 138-139.

KARASAR, Niyazi (1999), Bilimsel Araștırma Yöntemi, 9. Basım, Nobel Yay., Ankara.

KEKLIK, Nihat (1996), Türk İslam Felsefesi Açısından Felsefenin İlkeleri, İstanbul Üniversitesi Edebiyat Fakültesi Yayınları, Ankara.

PARLADIR, Selahattin (1984), İslamda Örgün Din Eğitimi, Dokuz Eylul University Graduate School of Social Sciences, (Unpublished Doctoral Dissertation), İzmir.

SÂTî EL-HUSRÎ (2001), Researches on Ibn Khaldun, (Trans., Süleyman Uludağ), Dergâh Yayınları, İstanbul.

ÜLKEN, Hilmi Ziya (2001), Eğitim Felsefesi, Ülken Yayınları, İstanbul.

YILDIRIM, Ali (2011), Qualitative Research Methods in Social Sciences, 8. Tıpkı Basım, Seçkin Yay., Ankara. 
Hacer Âşık Ev

34 | Celal Bayar Üniversitesi Sosyal Bilimler Dergisi - Cilt: 13, Sayı: 4, Aralık 2015 